Tests of Ex Ante versus Ex Post Theories of Collateral Using Private and Public Information

Allen N. Berger, W. Scott Frame, and Vasso Ioannidou

Working Paper 2010-6

March 2010

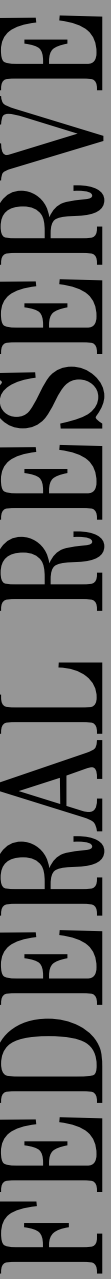




\title{
Tests of Ex Ante versus Ex Post Theories of Collateral Using Private and Public Information
}

\author{
Allen N. Berger, W. Scott Frame, and Vasso Ioannidou
}

\author{
Working Paper 2010-6 \\ March 2010
}

\begin{abstract}
Collateral is a widely used, but not well understood, debt-contracting feature. Two broad strands of theoretical literature explain collateral as arising from the existence of either ex ante private information or ex post incentive problems between borrowers and lenders. However, the extant empirical literature has been unable to isolate each of these effects. This paper attempts to do so using a credit registry that is unique in that it allows the researcher to have access to some private information about borrower risk that is unobserved by the lender. The data also include public information about borrower risk, loan contract terms, and ex post performance for both secured and unsecured loans. The results suggest that the ex post theories of collateral are empirically dominant although the ex ante theories are also valid for customers with short borrower-lender relationships that are relatively unknown to the lender.
\end{abstract}

JEL classification: G21, D82, G38

Key words: collateral, asymmetric information, banks

The authors thank the following for helpful comments and suggestions: an anonymous referee, Martin Brown, Marco Da Rin, Hans Degryse, Mark Flannery, Mariassunta Giannetti, Simon Kwan, Patrick Legros, Judit Montoriol-Garriga, Jan Krahnen, Bent Vale, Bas Werker, and Feng Wu. They also thank conference and seminar participants at the 2010 Allied Social Science Associations meetings, the 2009 European Finance Association meetings, the 2009 Financial Intermediation Research Society meetings, the 2009 Financial Management Association meetings, the conference "Business Models in Banking: Is There a Best Practice?" at Bocconi University, Pennsylvania State University, Sveriges Riskbank, and Tilburg University. The views expressed here are the authors' and not necessarily those of the Federal Reserve Bank of Atlanta or the Federal Reserve System. Any remaining errors are the authors' responsibility.

Please address questions regarding content to Allen N. Berger, Moore School of Business, University of South Carolina, 1705 College Street, Columbia, SC 29208, 803-576-8440, aberger@moore.sc.edu; W. Scott Frame, Research Department, Federal Reserve Bank of Atlanta, 1000 Peachtree Street, N.E., Atlanta, GA 30309-4470, 404-498-8783, scott.frame@atl.frb.org; or Vasso Ioannidou, CentER and Tilburg University, Department of Finance, 5000 LE, Tilburg, The Netherlands, 31-13-466-3097, v.p.ioannidou@uvt.nl.

Federal Reserve Bank of Atlanta working papers, including revised versions, are available on the Atlanta Fed's Web site at www.frbatlanta.org/pubs/WP/. Use the WebScriber Service at frbatlanta.org to receive e-mail notifications about new papers. 


\section{Tests of Ex Ante versus Ex Post Theories of Collateral using Private and Public Information}

\section{Introduction}

Collateral is a prominent feature of debt contracts. Residential and commercial mortgages, motor vehicle and equipment loans, and inter-bank repurchase agreements all rely heavily on readily marketable assets to secure funding. Interestingly, commercial loans only sometimes require collateral and the pledged assets tend to be quite heterogeneous.

The use of collateral in debt contracts can be costly for lenders, borrowers, and (in some cases) even society at large. Lenders incur costs of screening and monitoring the pledged assets, as well as any enforcement and disposal expenses in the case of repossession (e.g., Leeth and Scott 1989). Collateral may also impose opportunity costs on borrowers by tying up assets that might otherwise be put to more productive uses. ${ }^{1}$ As well, borrowers can suffer fluctuations in their credit availability as the values of their securable assets vary, particularly for loans secured by accounts receivable and/or inventory. In certain circumstances, collateral may also result in social costs (externalities) when changes in the value of widely pledged assets, like real estate, are correlated across borrowers and act to amplify the business cycle through procyclical changes in access to credit (e.g., Bernanke and Gertler 1989, 1990, Kiyatoki and Moore 1997). Recent research suggests that the significant decline in real estate collateral values in Japan in the early 1990s played an important role in reducing debt capacity and investment in that nation (Gan 2007). A similar procyclical effect may have occurred in the U.S. and other nations during the recent financial crisis, triggered in 2007 by the collapse in real estate collateral values.

Given that collateral is costly and yet widely employed, it is natural to inquire as to the economic functions of this contracting tool. Economic theory largely explains collateral as an attempt to either compensate for ex ante asymmetric information or as a method of reducing ex post incentive problems. Specifically, one set of theoretical models explains collateral as arising from ex ante information gaps between borrowers and lenders that can otherwise lead to an equilibrium characterized by adverse selection

\footnotetext{
${ }^{1}$ Renegotiations, which are frequent in private debt agreements (Smith, 1993), limit the cases in which assets are tied up in less productive uses and hence limit the opportunity costs to the borrower.
} 
and credit rationing in the spirit of Stiglitz and Weiss (1981). In this case, collateral allows lenders to sort observationally equivalent loan applicants through signaling. Specifically, lenders offer a menu of contract terms such that observationally equivalent applicants with higher-quality projects choose secured debt with lower risk premiums, while those with lower-quality projects self-select into unsecured debt with higher risk premiums (e.g., Bester 1985, 1987, Besanko and Thakor 1987a, 1987b, Chan and Thakor 1987, Boot, Thakor, and Udell 1991). A second set of theoretical models motivates collateral as part of an optimal debt contract by invoking ex post frictions. These may include moral hazard concerns (e.g., Boot, Thakor, and Udell 1991, Boot and Thakor 1994, Aghion and Bolton 1997, Holmstrom and Tirole 1997); difficulties in enforcing contracts (e.g., Banerjee and Newman 1993, Albuquerque and Hopenhayn 2004, Cooley, Marimon, and Quadrini 2004); and costly state verification (e.g., Townsend 1979, Gale and Hellwig 1985, Williamson 1986, Boyd and Smith 1994). Overall, the ex post theories predict that observably riskier borrowers are more likely to be required to pledge collateral.

In this paper, we test the empirical predictions generated by both the ex ante privateinformation/signaling models and the ex post models where collateral is used to overcome borrower/lender incentive conflicts. Our empirical test attempts to identify the effect of the two sets of theories by studying variation in the incidence of collateral pledges at loan origination. This test exploits differences in information that is available within a credit registry (and known to us) versus the information the registry discloses to prospective lenders. This provides us with clean measures of "private information” (information known to borrowers, but not to lenders) and "public information” (information known to both borrowers and lenders) with which to test the relevance of the two broad sets of collateral theories. By way of preview, our results are consistent with both sets of collateral theories, although the ex ante private information theories appear only to hold for borrowers that are relatively unknown to the lender (i.e., borrowers with short relationships).

The remainder of the paper is structured as follows. Section II provides a review of the related empirical literature. Section III describes the credit registry data and information sharing regime. Section IV 
outlines our empirical test and presents the results. Additional evidence is presented in Section V and Section VI concludes.

\section{Empirical Literature Review}

Some of the extant empirical literature pertaining to collateral, studies how collateral incidence relates to measures of borrower risk and proxies for private information. Consistent with the ex post theories, several studies find that observably riskier borrowers are more likely to pledge collateral. One study finds positive relations between financial leverage and collateral (Brick and Palia 2007), another finds that firms with better public ratings are less likely to pledge collateral (Gonas, Highfield, and Mullineaux 2004), and four others find positive relations between collateral and past observed repayment problems (Harhoff and Korting 1998; Chakraborty and Hu 2006, Jimenez, Salas, and Saurina 2006, and Brick and Palia 2007).

Studies testing theories concerning the importance of ex ante private information as a driver of collateral decisions have been much less successful. Many studies examine the effect of lender-borrower relationship strength on collateral incidence. The idea here is that stronger relationships (in terms of length, breadth, or intensity) will result in private information being revealed about the firm as lenders gather proprietary information about the borrower's character, reliability, and project choice over time (e.g., Petersen and Rajan 1994, Berger and Udell 1995, Degryse and van Cayseele 2000). However, the effect of access to private information on collateral pledges is ambiguous since this information may be favorable or unfavorable. The ex ante theories predict that unobservably safer borrowers pledge collateral. ${ }^{2}$

Not surprisingly, empirical tests of the role of relationship strength in determining whether collateral is pledged are mixed. Berger and Udell (1995), Harhoff and Korting (1998), Chakraborty and Hu (2006), and

\footnotetext{
${ }^{2}$ Furthermore, at least three other biases may influence the interpretation of these results. First, the more opaque the firm is, the more valuable is the private information to the lender - potentially leading to an information monopoly or "lockin" effect that would manifest itself through positive relations (e.g., Greenbaum, Kanatas, and Venezia 1989, Sharpe 1990, Rajan 1992). Second, a bias towards a positive association between collateral and relationship strength may occur if lenders use relationship lending technology for their most opaque borrowers (e.g., Berger, Espinosa-Vega, Frame, and Miller 2010). Finally, the results could be biased toward a negative association to the extent that collateral and relationships are substitute methods of dealing with opacity problems (e.g., Berger, Espinosa-Vega, Frame, and Miller 2010).
} 
Brick and Palia (2007) each reports finding that stronger relationships are inversely related to the incidence of collateral for loans drawn under lines of credit. Chakraborty and Hu (2006) also find that collateral is negatively related to relationship scope defined as the total number of financial services used by the firm. By contrast, several studies report that the incidence of collateral is positively related to an indicator of "main bank” or "house bank” (Machauer and Weber 1998, Elsas and Krahnen 2000, Degryse and Van Cayseele 2000, Lehmann and Neuberger 2001, and Menkhoff, Neuberger, and Suwanaporn 2006). Consistent with these latter studies, Ono and Uesugi (2009) find that relationship length is positively related to collateral for a sample of small Japanese firms.

More recent studies attempt to find other proxies for private information with which to test the ex ante theories of collateral. One study examines differences in informational opacity across borrowers, finding that more transparent firms are less likely to pledge collateral. Specifically, Gonas, Highfield, and Mullineaux (2004) find that large exchange-listed firms and those with public debt ratings are less likely to pledge collateral for bank loans. Another study exploits variation in lender information sets brought about by the use of credit scoring technology and finds that it reduces the incidence of collateral (Berger, Espinosa-Vega, Frame, and Miller 2010). While each of these studies succeeds in better identifying variation in the information environment across borrowers or lenders, none identifies borrower-specific private information as being favorable or unfavorable, and therefore none directly tests the key empirical implication of the ex ante theories.

One recent study attempts to do this using ex post default as a measure of ex ante adverse private information, finding that this measure is negatively related to the probability of pledging collateral at origination for young firms (Jimenez, Salas, and Saurina 2006). However, because collateral may raise the borrower's cost of default, one might expect to find that secured debt is less likely to default, irrespective of whether ex ante asymmetric information is important. Moreover, defaults may reflect moral hazard or other ex post frictions, and thus may not isolate the effects of ex ante private information.

Our methods improve upon this literature through the availability of data that allows us to empirically isolate the alternative theories of collateral: ex ante private information versus ex post contracting frictions. 
Specifically, our test exploits differences in information that is available within a credit registry (and known to us) versus the information the registry discloses to prospective lenders. This provides us with clean measures of private and public information with which to test the relevance of the two sets of collateral theories.

\section{Data and Information Environment}

Our analysis utilizes data from the Central de Información de Riesgos Crediticios (CIRC), the public credit registry of Bolivia, provided by the Bolivian Superintendent of Banks and Financial Entities (SBEF). Since CIRC's creation in 1989, the SBEF requires all formal (licensed and regulated) financial institutions operating in Bolivia to record information on all loans. Our sample covers the entire credit registry for the period between January 1998 and December 2003. For each loan, we have information on the date of origination, maturity date, contract terms, and ex post performance through the sample period. For each borrower, we have information about their industry, physical location, legal structure, banking relationships, and whether they have been delinquent or defaulted on a loan in the recent past.

The SBEF requires that some loan information is shared among the participating institutions to help alleviate the otherwise pervasive information asymmetries in the Bolivian credit markets. After written authorization from a prospective customer, a lender can access the registry and obtain a credit report, which contains information on all outstanding loans of the customer for the previous two months. Entries include originating bank, loan amount, type of loan, value of collateral, value of overdue payments, and the borrower's credit rating from the originating bank. Loans with overdue payments remain in the registry until they are paid off, even if they are past maturity. This implies that delinquencies in the past two months and past defaults from any previous period are observable to other lenders through the registry. By contrast, delinquencies that were paid off more than two months ago are not observable to other lenders through the registry (Campion 2001).

An underlying assumption that we maintain in the paper is that at least some of the information about past delinquencies does not become observable through other sources. There are several reasons why we think that this is a reasonable assumption. First, during the sample period, there was no other credit registry 
operational in Bolivia (de Janvry, Sadoulet, McIntosh, Wydick, Luoto, Gordillo, and Schuetz 2003). Second, Bolivian credit markets are quite opaque; the vast majority of firms do not have audited financial statements and the quality of existing financial statements is poor as many firms engage in tax evasion (Sirtaine, Skamnelos, and Frank, 2004). Third, evidence presented in Ioannidou and Ongena (forthcoming) is consistent with the assumption that at least some of this information remains unobserved as borrowers appear to use the two-month disclosure window strategically. The authors find that banks are unwilling to extend credit to new customers with observable repayment problems and that borrowers trying to switch to new banks clear due payments on their outstanding loans for those two months, manage to switch, but tend to return to nonperformance soon thereafter.

By having access to the entire credit registry, this information-sharing regime allows us to construct our indicators of observed and unobserved borrower risk - our key independent variables for testing the two collateral theories. We construct three indicators of observed risk: a dummy variable that equals one if the loan is given to a borrower that defaulted ${ }^{3}$ with any bank in the previous twelve months (Default_Observable_Registry), a dummy variable that equals one if the borrower had been 30+ days delinquent with any bank in the previous two months (Npl_Observable_Registry), and a dummy variable that equals one if the loan is given to a borrower that had been 30+ days delinquent with the same bank anytime from three to twelve months prior (Npl_Observable_Relationship). To measure unobserved risk, we create a dummy variable that equals one if the borrower had 30+ day delinquencies at other banks three to twelve months prior to the loan origination (Npl_Unobservable). Note that our empirical results below are materially unchanged if we expand the performance horizon back 18 or 24 months.

The data include loans from commercial banks and non-bank financial institutions (e.g., private financial funds, credit unions, mutual societies, and general deposit warehouses). To keep the set of lenders homogenous in terms of financial structure and regulation, we focus exclusively on commercial loans granted

\footnotetext{
3 "Default" occurs when the overdue payments are persistent enough for the bank to downgrade a loan to a rating of five and write-off the overdue amount. According to regulations, small loans (with an average amount smaller than US\$75,000) are downgraded to five if there are overdue payments for at least 121 days for secured loans and 91 days for unsecured loans. Large loans, by contrast, are downgraded to five when the borrower is considered insolvent (i.e., when the borrower's net worth is close to zero). In the sensitivity analysis below, we investigate the robustness of our findings by re-estimating our models separately for loans with contract amounts above or below US\$75,000.
} 
by commercial banks between March 1999 and December 2003. ${ }^{4}$ Table 1 provides a list of the 13 commercial banks that were active in Bolivia during the sample period, seven of which were foreign owned - four branches and three subsidiaries. $^{5}$ As shown in Table 1, five banks dominated the Bolivian banking sector during this time - each with total assets averaging at least US\$500 million and with more than 10 percent market share of deposits and loans. The Herfindahl-Hirschman Index for deposits is 1,292 and for loans it is 1,236, suggesting moderate market concentration.

Over the 1998 to 2003 period, the Bolivian economy slowed markedly due to the Russian/Asian financial crises, which resulted in currency depreciations for many emerging market currencies - including the Bolivian Peso. ${ }^{6}$ Note that while Bolivian bank assets and liabilities were largely denominated in U.S. dollars, wages and business income were largely paid in domestic currency. Hence, the currency depreciation had the effect of inflating debt-to-income ratios for consumers and firms - sending some into financial distress. As a result, bank balance sheets shrunk due to deposit withdrawals and weakened loan demand, and nonperforming loans increased. ${ }^{7}$ Despite the weakened macroeconomic and banking environment in Bolivia during our sample period, bank capital adequacy ratios remained above the 10 percent minimum requirement and actually increased over time - owing to shrinking balance sheets and government intervention in the form of low-cost loans and capital injections via subordinated debt (Sirtaine, Skamelos, and Frank 2004).

There are several types of commercial credit contracts in the data, including credit cards, overdrafts, installment loans, discount loans, and lines of credit. We focus exclusively on installment loans and discount loans and refer to these as "standard debt contracts." These contracts account for 92 percent of the total value

\footnotetext{
${ }^{4}$ Although we have data as of January 1998, we start our sample in March 1999 since prior to this date the data do not allow us to distinguish been commercial and consumer loans. However, we use the prior information from January 1998 through February 1999 to help fill in history on loans and relationships that existed as of March 1999.

${ }^{5}$ Foreign-owned banks operating in Bolivia have similar rights and responsibilities as domestically-owned institutions. One of the foreign branches, ABN Amro, left the Bolivian market in November 2000.

${ }^{6}$ The average annual growth rate of real GDP in Bolivia during the sample period was 2.2 percent, ranging between 0.7 and 3.7 percent.

${ }^{7}$ Bolivian nonperforming bank loans increased from US\$172 million (4.3 percent of total loans) in March 1999 to a peak of US\$570 million (20.3 percent of total loans) in June 2003.
} 
of commercial loans during the sample period. Of these contracts, 98 percent are denominated in U.S. dollars, and we use only these loans in our analysis.

Our sample encompasses 32,286 bank loans made to 2,676 different firms. A loan is defined by a unique identification code (loan id) and a date of origination. This includes new loans to new or existing customers, but also renegotiations of previous loans. Banks, however, are required to indicate whether a new loan is a renegotiation of a previous (performing or nonperforming) loan and we use this information to exclude renegotiations. ${ }^{8}$ We also do not include as new loans drawn on pre-existing lines of credit. ${ }^{9}$

Table 2 provides variable names, definitions, and summary statistics for all loans in the sample and for secured and unsecured loans separately. ${ }^{10}$ Collateral was pledged for 24.4 percent of the loans in the sample. As in the U.S., secured debt in Bolivia has effective priority over unsecured debt in bankruptcy (see Djankov, McLiesh, and Shleifer 2007). ${ }^{11}$ Of the 29,485 loans that matured before the end of the sample period, 6.4 percent had ex post delinquencies or defaults, with secured loans having a substantially higher incidence of repayment problems (9.1 percent as opposed to 5.5 percent for unsecured loans), suggesting that banks require collateral from riskier borrowers. The data also indicate that only 0.3 percent of the sample loans were given to borrowers that had defaulted in the prior twelve months (Default_Observable_Registry). This suggests that borrowers that default rarely get another loan, either because they are credit rationed or cease to exist as a going concern. Some 5.7 percent of the loans were issued to firms that had been delinquent with any bank in the two prior months (Npl_Observable_Registry). The data also show that 7.4 percent of the

\footnotetext{
${ }^{8}$ To the extent that some renegotiations are not recorded (either because of reporting errors or because banks do that intentionally to reduce their loan loss reserves), our sample would include some renegotiations as new loans. Hence, in the sensitivity analysis below we try to control for this possibility by dropping all "suspected renegotiations" from our sample.

${ }^{9}$ When a borrower draws on a pre-existing line of credit, a "new loan" appears in the registry with origination date and contract terms as of the date the bank originated the credit line. Since the date the loan first appears in the registry is subsequent to the origination date, we can identify when a "new loan" is a draw on a pre-existing line of credit and exclude it from our sample.

${ }^{10}$ For relationship length, loan amount, and maturity we report summary statistics for the level of these variables, but our empirical models (below) incorporate the natural logarithm of one plus the level.

${ }^{11}$ The data used in Djankov, McLiesh, and Shleifer (2007) are available at: http://www.economics.harvard.edu/faculty/shleifer/dataset.
} 
credits were issued to firms that had been delinquent with the same bank anytime from three to twelve months prior (Npl_Observable_Relationship). Finally, 14.0 percent of loans were given to borrowers with delinquencies at other banks from three to twelve months prior to the loan origination (Npl_Unobservable). As mentioned earlier, this last information item is not revealed to the lender through the credit registry but, as our empirical analysis below suggests, it might be revealed through lending relationships.

Turning to the control variables, the average banking relationship in the sample is 23.1 months. This is defined as the number of months since the first loan of this borrower from this bank in the registry since January 1998. Most of the sample firms are corporations (71.4 percent), while partnerships (14.0 percent) and sole proprietorships (12.5 percent) are much less common. Almost one-half of the sample is comprised of installment loans. The average loan amount is US\$161,490 and the average loan maturity is about 12 months. As expected, secured and unsecured loans have different contract terms. On average, secured loans are more than twice as large and have maturities that are six months longer.

\section{Empirical Analysis}

Our empirical test relates the incidence of collateral to measures of observed and unobserved borrower risk, the length of the banking relationship, loan- and firm-level control variables, and bank and time fixed effects. This model, which is estimated using Probit, can be summarized as:

$$
\begin{gathered}
P\left(\text { Collateral }_{i j t}\right)= \\
f\left(\text { Observed_Risk }_{i j t}, \text { Unobserved_Risk }_{i j t}, \text { Unobserved_Risk }_{i j t}{ }^{*} \text { Rel_Length }_{i j t},\right. \\
\text { Rel_Length } \left._{i j t}, \text { Firm }_{i j t}, \text { Loan }_{i j t}, \alpha_{j}, \gamma_{t}\right)
\end{gathered}
$$

where $P(\bullet)$ indicates probability, Collateral ${ }_{i j t}$ is a dummy variable that equals 1 if the loan is secured, and $i, j$, and $t$ index loans, banks, and time, respectively. The key exogenous variables are those capturing observed and unobserved borrower risk as we defined in Table 2. Specifically, Observed_Risk $k_{i j t}$ is comprised of the three dummy variables that indicate the observed riskiness of the borrower at loan origination: Default_Observable_Registry, Npl_Observable_Registry, and Npl_Observable_Relationship. 
Unobserved_Risk ${ }_{i j t}$ is comprised of a single dummy variable, $N p l \_U n o b s e r v a b l e$. As mentioned earlier, this variable is in the credit registry and thus available to us, but not available to the lender. By using these four indicators of borrower risk, we essentially assume that past performance, observable or unobservable, is predictive of future performance. That is, we assume that borrowers with past repayment problems are more likely to have delinquencies or defaults on future loans. The Appendix demonstrates that this is indeed the case.

A positive, statistically and economically significant coefficient for any of the three variables included in Observed_Risk $k_{i j t}$ would be evidence in favor of the ex post theories. That is, observably risky borrowers are more likely to be required by lenders to post collateral. By contrast, a negative, statistically and economically significant coefficient on Unobserved_Risk $k_{i j t}$ would be consistent with the ex ante theories. That is, according to models of signaling, firms with private information that they are "good" are more likely to pledge collateral. As mentioned earlier such a finding would require that the Unobserved_Risk $k_{i j t}$ variable does not indirectly become observable through other sources. For example, some of this information might have become known to the lender if the borrower previously applied for a loan to the same bank that was not granted or if this information is demanded in loan applications. To the extent that this occurs, it would bias our results against finding evidence consistent with the ex ante theories. In fact, in the limiting case in which all of the information in Unobserved_Risk $k_{i j t}$ becomes observable to the originating bank, we should find that the estimated coefficient of Unobserved_Risk $k_{i j t}$ is positive and statistically significant.

To account for the likelihood that a firm's private information declines in the length of the bank-firm relationship, we also include the interaction term Unobserved_Risk $k_{i j t} *$ Rel_Length ${ }_{i j t}$, where Rel_Length ${ }_{i j t}$ is measured as the natural logarithm of one plus the number of months that we observe the bank and borrower in a relationship. We expect that the empirical relevance of the ex ante theories diminishes as the length of a bank-firm relationship increases, suggesting a negative coefficient for Unobserved_Risk $k_{i j t}$ and a positive coefficient for Unobserved_Risk $k_{i j t} *$ Rel_Length $h_{i j t}$. In other words, borrowers with favorable private information choose to pledge collateral to signal their quality only when relationships are short and the bank 
does not know their quality. Finally, if relationships mitigate informational asymmetries, the coefficient of Rel_Length ${ }_{i j t}$ should be negative.

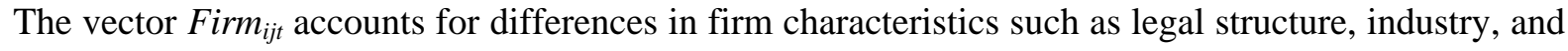
region. We use a set of dummy variables indicating the legal structure of the firm: Partnership, Corporation, and Other (Sole_Proprietorship is the omitted group). Industry is a set of 18 dummy variables controlling for the firm's industry classification (like the SIC or NAICS codes). Region is a set of dummy variables that indicate the location from which the bank originated the loan. This includes nine regions in Bolivia as well as Argentina, Paraguay, Panama, and the United States.

The vector $\operatorname{Loan}_{i j t}$ accounts for differences in the individual loan contract terms. However, each of these terms could be determined simultaneously with collateral, and is potentially endogenous. We therefore estimate our empirical models both with and without these variables. Installment is a dummy variable equal to one if the contract is an installment loan rather than a discount loan. Loan_Amount is measured as the natural logarithm of one plus the amount of the loan proceeds at origination in U.S. dollars. Maturity is the natural logarithm of one plus the number of months between loan origination and maturity. We explicitly exclude the loan interest rate since it is jointly determined with collateral under the ex ante theories.

Bank and time (month) fixed effects are also included in the model, represented by the scalars $\alpha_{\mathrm{j}}$ and $\gamma_{t}$, respectively. Bank fixed effects should capture any systematic differences in bank propensities to require collateral for their commercial loans. The time fixed effects are intended to account for temporal differences in required collateral related to the business or credit cycle. Accounting for such variation may be important given the volatile macro-financial environment in Bolivia during the period under study.

Estimation results are presented in Table 3. In Column I, we report a benchmark specification without interaction terms and loan characteristics. In Column II, we include the interaction term between the length of a bank-firm relationship and unobserved risk, and in Column III, we also add loan characteristics. Under the heading Probit Coefficients, we report the estimated coefficients of the three Probit specifications. Under the heading Marginal Effects, we report the change in probability of pledging collateral for each one of the independent variables, holding all other independent variables at their sample means. For continuous 
variables, we report the effect for an infinitesimal change in the variable; and for dummy variables we report the estimated effect of a change from 0 to 1.

In all three specifications, our three indicators of observed risk are positively associated with the incidence of collateral. These findings are consistent with the ex post theories, under which observably riskier borrowers are asked to pledge collateral to mitigate frictions such as moral hazard. Each of these indicators of previous delinquencies or defaults is estimated to be associated with a 3.9 to 12.8 percentage point estimated increase in the probability of collateral being pledged. These findings are economically significant, given that the predicted probability of collateral at the mean of all independent variables (P0) is only about 20\%.

The estimated coefficient of Unobserved Risk is neither statistically neither economically significant in Column I. However, when we include the interaction term between unobserved risk and relationship length, the measured effect of unobserved risk becomes both statistically and economically significant. For "new" borrowers, for whom relationship length is zero, unobserved risk is associated with 13.7 to 17.0 percentage point decrease in the probability of collateral, consistent with the ex ante theories. Combining the marginal effects of Unobserved Risk and the interaction term suggests that the effect is negative for relationships under approximately seven months. ${ }^{12,13}$ This is consistent with a reduction in private information with longer relationships. ${ }^{14}$ Thus, the data suggest that the ex ante theories only hold for loans to borrowers with relatively short relationships when asymmetric information problems are more likely to be present. Relationship length itself is significantly negatively related to the incidence of collateral. This is also consistent with the literature that banking relationships assist in resolving asymmetric information problems.

The incidence of collateral is lower for loans to partnerships or corporations than for those to sole proprietorships (the omitted category), consistent with collateral being more likely for opaque firms.

\footnotetext{
${ }^{12}$ In Column II, the effect of unobserved risk equals zero for relationship length $x$ when $-0.17+0.082 * \ln (1+x)=0$, which is solved for $x$ equal to 6.9. For the estimates in Column III, the corresponding $x$ equals 6.7.

${ }^{13}$ This is consistent with Cole (1998), who finds that most of the borrower information is collected within the first year of a relationship.

${ }^{14}$ One way in which private information might be revealed to the bank when relationships are longer is through past draws on the credit registry.
} 
Installment loans are less likely to have collateral pledged, but larger loans and those with longer maturities are more likely to be associated with collateral pledges.

We conduct four robustness checks. First, we include a number of additional relationship characteristics to the specification reported in Column II of Table 3. Specifically, we include a dummy variable for multiple banking relationships, a dummy variable for when the bank is the firm's primary lender (i.e., more than 50 percent of outstanding loan balances are from that bank), and a dummy variable for the existence of other lending products such as other loans, credit cards, credit lines, and overdrafts in the current account. The empirical results are materially unchanged by including additional relationship metrics.

Second, we estimate the model separately for installment and discount loans. The results are very similar to those reported in Column II of Table 3. One difference is that the estimated coefficients of Default_Observable_Registry and Npl_Observable_Relationship in the discount loans equations are not statistically significant. However, the estimated coefficient of the third indicator of observed borrower risk, Npl_Observable_Registry, remains positive and statistically significant, supporting the ex post theories.

Third, we estimate the model separately for loans with contract amounts above and below US\$75,000. The results are very similar to those reported earlier, with the exception of the coefficient of Default_Observable_Registry that is not statistically significant in the sample of loans with a contract amount below US\$75,000.

Finally, we include the loan interest rate at origination to the vector of loan characteristics included in the specification reported in Column III of Table 3. While the interest rate is found to have negative and statistically significant relations with the incidence of collateral, including this variable had no material effect on our results.

\section{Additional Evidence}

We believe that studying the effects of observed and unobserved borrower risk on the incidence of collateral is the most appropriate way for empirically testing the two sets of collateral theories because it allows identification of the individual effects. There is, however, an empirical literature that relates measures 
of borrower risk (such as the loan risk premium and ex post loan performance) to whether or not collateral was pledged for a given credit. In this case, one might be able to surmise whether the ex ante private information theories or the ex post incentive conflict models dominate empirically, but only under certain circumstances.

Most of the studies relating borrower risk to the incidence of collateral use the risk premium paid on the credit (yield less the risk free rate) as the borrower risk measure. Several studies report positive relations between risk premiums and collateral pledges (Berger and Udell 1990, Blackwell and Winters 1997, Machauer and Weber 1998, John, Lynch, and Puri 2003, and Brick and Palia 2007); although two other studies report negative relations (Degryse and Van Cayseele 2000, Lehmann and Neuberger 2001). Jimenez and Saurina (2004), on the other hand, use ex post loan nonperformance as measure of borrower risk and find that loan defaults are positively related to collateral pledges. ${ }^{15}$

For comparative purposes, we estimate similar empirical relations using loan risk premiums and ex post loan nonperformance as risk measures. We define Risk_Premium $i j t$ as the loan interest rate (at origination) minus the rate on the six-month U.S. Treasury bill at the end of the same month. ${ }^{16}$ Ex_Post_Nonperformance ${ }_{i j t}$ is a dummy variable that equals one if the loan eventually becomes delinquent or defaults. ${ }^{17}$ Both of these measures are regressed on a dummy variable indicating that collateral was pledged, the length of the banking relationship, the interaction of these two variables, loan- and firm-level control variables, and bank and time fixed effects as summarized below:

Risk_Premium $_{i j t}=g\left(\right.$ Collateral $_{i j t}$, Collateral $_{i j t} *$ Rel_Length ${ }_{i j t}$, Rel_Length $_{i j t}$, Firm $_{i j t}$, Loan $\left._{i j t}, \alpha_{j}, \gamma_{t}\right)$

\footnotetext{
${ }^{15}$ In an earlier study, Berger and Udell (1990) use bank-level data to study the association between the quality of the loan portfolio and the proportion of loans that were collateralized.

${ }^{16}$ The six-month U.S. Treasury rate is used because the median loan in the sample has a maturity of seven months and all loans are denominated in U.S. dollars. Estimating relations using the rate on the three-month Treasury bill had no material effect on the results.

${ }^{17}$ For consistency with Jimenez and Saurina (2004), we also estimate relations using the probability of default as the dependent variable in place of the probability of delinquency or default (i.e., we adopt a more conservative definition of nonperformance). Again, the signs and significance of the results are virtually unchanged.
} 


$$
\begin{gathered}
P\left(\text { Ex_Post_Nonperformance }_{i j t}\right)=h\left(\text { Collateral }_{i j t}, \text { Collateral }_{i j t} * \text { Rel_Length }_{i j t}, \text { Rel_Length }_{i j t},\right. \\
\text { Firm } \left._{i j t}, \operatorname{Loan}_{i j}, \alpha_{j}, \gamma_{t}\right) .
\end{gathered}
$$

From a theoretical perspective, the measured effect of collateral on borrower risk in (2) and (3) is ambiguous. Under the ex post theories, collateral is required of observably riskier borrowers who are more likely to pay higher interest rates and have performance problems. But this effect could be offset - or even overturned - to the extent that collateral mitigates or eliminates the ex post frictions. The effective priority of secured debt in bankruptcy mitigates incentives for moral hazard (e.g., it reduces asset/project substitution and prevents borrowers from obtaining additional debt which jeopardizes the lender's claims) and reduces the lender's loss given default (e.g., by increasing the seniority of secured debt over unsecured debt and by facilitating the repossession of the property and thus reducing foreclosure costs). Hence, all else equal, the effective priority of secured debt should lead to smaller loan rate premiums (Smith and Warner, 1979a, 1979b).

Under the ex ante private information theories, the measured effect of collateral is expected to be negative since it is the unobservably safer borrowers who pledge collateral more often and hence pay lower interest rates and are less likely to have performance problems. Thus, a positive measured effect of collateral on risk premiums or ex post nonperformance would suggest a net empirical dominance of the ex post theories. By contrast, a negative measured effect would suggest either a net empirical dominance of the ex ante private information theories, an overcompensating effect of collateral under the ex post theories, or both.

As in equation (1), we also include the interaction term between collateral and relationship length, Collateral $_{i j t}{ }^{*}$ Rel_Length ${ }_{i j t}$, because the ex ante theories are less likely to hold when the relationship is long and the bank has had time to discover more of the private information about the firm. Thus, we expect a positive sign on the interaction term in equations (2) and (3), as the ex post theories are more likely to empirically dominate when relationships are longer. All firm and loan control variables and bank and time fixed effects are the same as in equation (1).

Ordinary least squares (OLS) estimates for equation (2) are presented in Table 4. Column I reports a 
benchmark specification without the collateral-relationship length interaction term or loan characteristics. Column II introduces the interaction term, and Column III also includes the potentially endogenous loan characteristics. In all three specifications, we find strong negative relations between loan risk premiums and the incidence of collateral. This suggests that borrowers pledging collateral generally receive a lower interest rate - consistent with either a net empirical dominance of the ex ante private information theories, an overcompensating effect of collateral under the ex post theories, or both. However, it is also the case that this negative effect is mitigated to some extent by long-term borrower-lender relationships - suggesting that as private information is revealed over time the discounts dissipate (see Columns II and III). Consistent with our previous findings, this result suggests that the ex post theories are more relevant when relationships are more established.

With respect to the control variables, we find that relationship length has a positive and statistically significant coefficient in Column I when an interaction term is not included, while it is essentially zero in Columns II and III. We also find that firms organized as partnerships and corporations pay lower average loan risk premiums than sole proprietorships. This is consistent with proprietorships generally being riskier and more informationally opaque than other types of firms. Regarding contract terms, it appears that installment loans carry higher interest rates, while larger loans and loans with longer maturities carry lower interest rates.

Table 5 presents the results for ExPost_Nonperformance $i j$, both in terms of the Probit coefficients and marginal effects. Note that for this analysis, we drop all loans that do not mature before the end of the sample (December 2003); thereby leaving 29,485 bank loans. Since this has the effect of reducing the average loan maturity in our sample, we also eliminate all loans originated during the last six months of the sample (July December 2003) - further reducing the sample to 28,758 loans.

In Column I, collateral is positively associated with ex post delinquencies or defaults, consistent with net empirical dominance of the ex post theories. The estimated marginal effect suggests a 4.1 percentage point increase in the probability of ex post nonperformance for secured loans. This effect is economically significant, since the predicted probability of ex post nonperformance at the mean of all independent variables 
(P0) is 4.7 percent. This suggests that secured loans are almost twice as likely to have repayment problems as unsecured loans. However, when the interaction term is introduced in Column II, the results change substantially. The coefficient on collateral becomes zero implying that there is no net effect of collateral when the customer is new to the bank (i.e., when relationship length is zero). However, the positive coefficient of the interaction term implies that for longer relationships, the measured effect of collateral is positive. This is again consistent with the net empirical dominance of the ex post theories for seasoned customers.

The independent effect of relationship length is essentially zero in Column I when no interaction term is included. The negative coefficient for relationship length in Columns II and III implies that when no collateral is pledged, firms with longer relationships are less likely to have nonperformance problems, consistent with expectations that such borrowers are less risky. ${ }^{18}$ With respect to the other control variables, we find that partnerships and corporations are more likely to have loan performance problems than sole proprietorships. This is consistent with limited liability playing a role in default decisions. Regarding contract terms, it appears that installment loans and loans with longer maturities are associated with a higher incidence of repayment problems. Larger loans, by contrast, are negatively associated with ex post nonperformance.

As a robustness check, we re-estimate the specifications reported in Table 5 separately for loans with contract amounts above and below US\$75,000. Results are similar to those reported in Table 5. We also reestimate the specifications reported in Table 5 after dropping all loans that appear to be renegotiations of previous loans. (Recall that loans designated in the registry as renegotiations have already been excluded from this analysis.) Including such loans could bias the estimated relations between ex post nonperformance and collateral. This bias would arise in situations in which the borrower became distressed and the bank demanded that collateral is pledged, but recorded the adjustment as a new loan (see, for example, discussions in Smith 1993 and DeAngelo, DeAngelo, and Wruck 2002). To identify such situations, we look for loans

\footnotetext{
${ }^{18}$ Note that although borrowers with longer relationships appear to be less risky on average they do not pay lower risk premiums (see Columns II and III in Table 4). This is consistent with the extraction of information rents as in Sharpe (1990) and von Thadden (2004). See also Ioannidou and Ongena (forthcoming) for evidence consistent with this hypothesis.
} 
that are originated right after another loan at the same bank terminates. We identify 5,962 such loans, of which only 424 have collateral added. Re-estimating equation (3) without these loans has no effect on our results.

\section{Conclusions}

The theoretical literature offers two broad classes of theories about why borrowers pledge collateral. The first set of theories motivates collateral as a way for good borrowers to signal their quality under conditions of ex ante private information. The second set of theories explains collateral as an optimal response to ex post contract frictions like moral hazard. A growing body of literature that empirically tests these models and the on-going financial crisis have raised significant academic and policy interest in understanding the role of collateral in debt contracts.

This paper improves upon the empirical literature by using data from the Bolivian public credit registry that provides us with important risk information about the borrower that is not known to the lender. Thus, we have both "private” and "public" information about the firm. Using this information structure, we are able to construct measures of both observed and unobserved risk and hence more effectively test the two sets of collateral theories. The data also allows us to explore the role of banking relationships and how information gleaned from relationships reduces private information.

We present results that suggest roles for both sets of theories, although the ex ante private information theories appear to hold only for customers with short relationships that are relatively unknown to the lender. The data also suggest that the ex post theories tend to empirically dominate for firms with long relationships, where private information is less important.

Our analysis represents an important contribution to the literature seeking to understand the motivation for collateral in debt contracts. First, the issue has clearly been on the minds of market participants and policymakers in places like Japan and the United States owing to significant shocks to collateral values. Second, we use credit registry data that allows us to produce clean measures of private and public information, as well as providing a rich set of controls at the loan and bank level and bank and time fixed effects to account 
for unobserved bank heterogeneity and changes in the lending environment, respectively. Our approach might also be relevant to World Bank efforts to encourage the establishment of the development of credit registries in the developing world. Our findings suggest that the information provided by such registries might be useful in eliminating the need for costly collateral. 


\section{References}

Aghion, Philippe and Patrick Bolton (1997). “A Theory of Trickle-Down Growth and Development,” Review of Economic Studies, 64, 151-172.

Albuquerque, Rui and Hugo A. Hopenhayn (2004). “Optimal Lending Contracts and Firm Dynamics,” Review of Economic Studies, 71, 285-315.

Banerjee, Abhijit V. and Andrew F. Newman (1993). "Occupational Choice and the Process of Development,” Journal of Political Economy, 101, 274-298.

Berger, Allen N. and Gregory F. Udell (1990). “Collateral, Loan Quality, and Bank Risk,” Journal of Monetary Economics, 25, 21-42.

Berger, Allen N. and Gregory F. Udell (1995). "Relationship Lending and Lines of Credit in Small Firm Finance,” Journal of Business, 68, 351-381.

Berger, Allen N., Marco A. Espinosa-Vega, W. Scott Frame, and Nathan H. Miller (2010). "Why Do Borrowers Pledge Collateral? New Empirical Evidence on the Role of Asymmetric Information," Journal of Financial Intermediation.

Bernanke, Ben and Mark Gertler (1989). “Agency Costs, Net Worth, and Business Fluctuations,” American Economic Review, 79, 14-31.

Bernanke, Ben S. and Mark Gertler (1990). "Financial Fragility and Economic Performance,” Quarterly Journal of Economics, 105, 87-114.

Besanko, David and Anjan V. Thakor (1987a). "Collateral and Rationing: Sorting Equilibria in Monopolistic and Competitive Credit Markets,” International Economic Review, 28, 671-689.

Besanko, David and Anjan V. Thakor (1987b). "Competitive Equilibrium in the Credit Market under Asymmetric Information,” Journal of Economic Theory, 42, 167-183.

Bester, Helmut (1985). “Screening vs. Rationing in Credit Markets with Imperfect Information,” American Economic Review, 75, 850-855.

Bester, Helmut (1987). "The Role of Collateral in Credit Markets with Imperfect Information,” European Economic Review, 106, 60-75.

Blackwell, David W. and Drew B. Winters (1997). "Banking Relationships and the Effect of Monitoring on Loan Pricing,” Journal of Financial Research, 20, 275-289.

Boot, Arnoud W.A. and Anjan V. Thakor (1994). "Moral Hazard and Secured Lending in an Infinitely Repeated Credit Market Game,” International Economic Review, 35, 899-920.

Boot, Arnoud W.A., Anjan V. Thakor, and Gregory F. Udell (1991). "Secured Lending and Default Risk: Equilibrium Analysis, Policy Implications and Empirical Results,” Economic Journal, 101, 458-472.

Boyd, John H. and Bruce D. Smith (1994). "The Equilibrium Allocation of Investment Capital in the Presence of Adverse Selection and Costly State Verification,” Economic Theory, 3, 427-451. 
Brick, Ivan E. and Darius Palia (2007). "Evidence of Jointness in the Terms of Relationship Lending," Journal of Financial Intermediation, 16, 452-476.

Campion, Anita (2001). “Client Information Sharing in Bolivia,” Journal of Microfinance, 3, 45-63.

Chakraborty, Atreya and Charles X. Hu (2006). "Lending Relationships in Line-of-Credit and Nonline-ofCredit Loans: Evidence from Collateral use in Small Business,” Journal of Financial Intermediation, 15, 86107.

Chan, Yuk-Shee, and Anjan V. Thakor (1987). "Collateral and Competitive Equilibria with Moral Hazard and Private Information,” Journal of Finance, 42, 345-363.

Cole, Rebel A. (1998). The Importance of Relationships to the Availability of Credit, Journal of Banking and Finance, 22, 959-977.

Cooley, Thomas, Ramon Marimon, and Vincenzo Quadrini (2004). “Aggregate Consequences of Limited Contract Enforceability,” Journal of Political Economy, 112, 817-847.

DeAngelo, Harry, Linda DeAngelo, and Karen H. Wruck (2002). “Asset Liquidity, Debt Covenants, and Managerial Discretion in Financial Distress: the Collapse of L.A. Gear," Journal of Financial Economics, 64, 3-34.

Djankov, Simeon, Caralee McLiesh, and Andrei Shleifer (2007), “Private Credit in 129 Countries,” Journal of Financial Economics, 84, 299-329.

de Janvry, Alain, Elisabeth Sadoulet, Craig McIntosh, Bruce Wydick, Jill Luoto, Gustavo Gordillo, and Guilherme Schuetz (2003). "Credit Bureaus and the Rural Microfinance Sector: Peru, Guatemala, and Bolivia," Joint Project with the University of California at Berkeley and the Food and Agricultural Office for Latin America, available at: http://areweb.berkeley.edu/fields/development/microfinance.php.

Degryse, Hans and Patrick Van Cayseele (2000). "Relationship Lending within a Bank-Based System: Evidence from European Small Business Data,” Journal of Financial Intermediation, 9, 90-109.

Elsas, Ralf and Jan Pieter Krahnen (2000). "Collateral, Default Risk, and Relationship Lending: An Empirical Study on Financial Contracting.” CEPR Discussion Paper 2540.

Gale, Douglas and Martin Hellwig (1985). "Incentive-Compatible Debt Contracts: The One-Period Problem,” Review of Economic Studies, 52, 647-663.

Gan, Jie (2007). “Collateral, Debt Capacity, and Corporate Investment: Evidence from a Natural Experiment,” Journal of Financial Economics, 85, 709-734.

Gonas, John S., Michael Highfield, and Donald Mullineaux (2004). “When are Commercial Loans Secured?” Financial Review, 39, 79-99.

Greenbaum, Stuart I., George Kanatas, and Itzhak Venezia (1989). "Equilibrium Loan Pricing under the Bank-Client Relationship,” Journal of Banking and Finance, 13, 221-235.

Holmstrom, Bengt and Jean Tirole (1997). "Financial Intermediation, Loanable Funds, and the Real Sector," Quarterly Journal of Economics, 62, 663-691. 
Harhoff, Dietmar and Timm Korting (1998). "Lending Relationships in Germany - Empirical Evidence from Survey Data,” Journal of Banking and Finance, 22, 1317-1353.

Ioannidou, Vasso and Steven Ongena (forthcoming). “Time for a Change: Loan Conditions and Bank Behavior when Firms Switch Banks,” Journal of Finance.

Jimenez, Gabriel, Vincente Salas, and Jesus Saurina (2006). “Determinants of Collateral,” Journal of Financial Economics, 81, 255-281.

Jimenez, Gabriel, and Jesus Saurina (2004). "Collateral, Type of Lender and Relationship Banking as Determinants of Credit Risk,” Journal of Banking and Finance, 28, 2191-2212.

John, Kose, Anthony W. Lynch and Manju Puri (2003). "Credit Ratings, Collateral, and Loan Characteristics: Implications for Yield,” Journal of Business, 76, 371-409.

Kiyatoki, Nobuhiro and John Moore (1997). “Credit Cycles,” Journal of Political Economy, 105, 211-248.

Leeth, John D. and Jonathan Scott (1989). "The Incidence of Secured Debt: Evidence from the Small Business Community,” Journal of Financial and Quantitative Analysis, 24, 379-394.

Lehmann, Erik and Doris Neuberger (2001). "Do Lending Relationships Matter? Evidence from Bank Survey Data in Germany,” Journal of Economic Behavior and Organization, 45, 339-359.

Machauer, Achim and Martin Weber (1998). "Bank Behavior Based on Internal Credit Ratings of Borrowers,” Journal of Banking and Finance, 22, 1355-1383.

Menkhoff, Lukas, Doris Neuberger, and Chodechai Suwanaporn (2006). "Collateral-based Lending in Emerging Markets: Evidence from Thailand," Journal of Banking and Finance, 30, 1-21.

Ono, Arito and Iichiro Uesugi (2009). "Role of Collateral and Personal Guarantees in Relationship Lending: Evidence from Japan’s SME Loan Market,” Journal of Money, Credit, and Banking, 41, 935-960.

Petersen, Mitchell A. and Raghuram G. Rajan (1994). "The Benefits of Lending Relationships: Evidence from Small Business Data,” Journal of Finance, 110, 407-443.

Rajan, Raghuram G. (1992). Insiders and Outsiders: The Choice between Informed and Arm's-Length Debt,” Journal of Finance, 47, 1367-1400.

Sharpe, Steven A. (1990). “Asymmetric Information, Bank Lending, and Implicit Contracts: A Stylized Model of Customer Relationships,” Journal of Finance, 45, 1069-1087.

Smith, Clifford W. Jr. (1993). “A Perspective on Accounting-Based Debt Covenant Violations,” The Accounting Review, 68, 289-303.

Smith, Clifford W. Jr. and Jerold B. Warner (1979a). "Bankruptcy, Secured Debt, and Optimal Capital Structure: Comment,” The Journal of Finance, 34, 247-251.

Smith, Clifford W. Jr. and Jerold B. Warner (1979b). “On Financial Contracting: An Analysis of Bond Covenants,” Journal of Financial Economics, 7, 117-161.

Sirtaine, Sophie, Ilias Skamnelos, and Sissy Frank (2004). Bolivia: Challenges in the Corporate and Banking Sectors, World Bank: Washington DC. 
Stiglitz, Joseph E. and Andrew Weiss (1981). "Credit Rationing in Markets with Imperfect Information,” American Economic Review, 71, 393-410.

Townsend, Robert M. (1979). "Optimal Contracts and Competitive Markets with Costly State Verification," Journal of Economic Theory, 21, 265-293.

Williamson, Stephen D. (1986). "Costly Monitoring, Financial Intermediation and Equilibrium Credit Rationing,” Journal of Monetary Economics, 18, 159-179.

von Thadden, Ernst L. (2004). "Asymmetric Information, Bank Lending, and Implicit Contracts: The Winner's Curse,” Finance Research Letters, 1, 11-23. 


\section{Appendix}

Our empirical analysis rests on the maintained assumption that past loan performance is predictive of future loan performance. That is, borrowers with past repayment problems are more likely to become delinquent or default on future loans. To investigate whether this assumption holds for our sample, we examine how our four measures of risk based on past repayment histories relate to the performance of new loans using the following Probit model:

$$
\begin{aligned}
P\left(E_{-} \text {Post_Nonperformance }_{i j t}\right) & =h\left(\text { Observed_Risk }_{i j t}, \text { Unobserved_Risk }_{i j t},\right. \\
& \text { Rel_Length } \left._{i j t}, \text { Firm }_{i j t}, \operatorname{Loan}_{i j}, \alpha_{j}, \gamma_{t}\right),
\end{aligned}
$$

where Ex_Post_Nonperformance $e_{i j t}$ is a dummy variable that equals 1 if the loan is $30+$ days overdue anytime after origination or if it enters default status. All other variables are defined as in equation (1). The model is estimated using the 28,758 loans that were originated prior to the last six months of the sample and matured before the end of the sample.

The estimation results are presented in Table A1. ${ }^{19}$ In Column I we report results from a benchmark specification without loan characteristics, while Column II reports results from a model including loan characteristics. Under the heading Probit Coefficients, we report the estimated coefficients of the two Probit specifications, while under the heading Marginal Effects, we report the change in probability of ex post nonperformance for each one of the independent variables, holding all other independent variables at their sample means. For continuous variables, we report the effect for an infinitesimal change in the variable; and for dummy variables we report the estimated effect of a change from 0 to 1 .

In both specifications, all four indicators of borrower risk based on past repayment histories are positively correlated with repayment problems on the new loan. This suggests that past performance is indeed predictive of future performance. Moreover, considering that the predicted probability of the new loan

\footnotetext{
${ }^{19}$ Results are similar if we estimate the model separately for loans above or below US\$75,000.
} 
becoming "nonperforming” (at the mean of all dependent variables, $\mathrm{P} 0$ ) is around 4\%, the estimated marginal effects of these four risk indicators are quite large.

\section{Table A1}

\section{Past Performance is Predictive of Future Performance}

This table reports Probit regressions for Ex Post Nonperformance, a dummy variable that equals one if a loan is 30+ days overdue anytime after its origination or if it is downgraded to the default status (i.e., given a rating of 5). Under Probit Coefficients we report the estimated coefficients of the two Probit specifications. Standard errors, corrected for heteroskedasticity, are reported between brackets. Under Marginal Effects we report the change in probability of pledging collateral for each one of the independent variables. For continuous variables we report the effect for an infinitesimal change in each independent variable and for dummy variables we report the estimated effect of a change from 0 to 1 . P0 is the predicted probability of ex post nonperformance, evaluated at the mean of all independent variables. ${ }^{* * *}, * *$, and $*$ indicate significance at the $1 \%, 5 \%$, and $10 \%$, respectively.

\begin{tabular}{|c|c|c|c|c|}
\hline & \multicolumn{2}{|c|}{ Probit Coefficients } & \multicolumn{2}{|c|}{ Marginal Effects } \\
\hline & I & II & I & II \\
\hline \multicolumn{5}{|l|}{ Observed Risk } \\
\hline \multirow[t]{2}{*}{ Default_Observable_Registry } & 0.081 & 0.05 & 0.008 & 0.004 \\
\hline & {$[0.189]$} & {$[0.190]$} & [0.019] & {$[0.018]$} \\
\hline \multirow[t]{2}{*}{ Npl_Observable_Registry } & $0.512 * * *$ & $0.546 * * *$ & $0.067 * * *$ & $0.071 * * *$ \\
\hline & {$[0.045]$} & {$[0.046]$} & {$[0.008]$} & {$[0.008]$} \\
\hline Npl_Observable_Relationship & $\begin{array}{l}0.729 * * * \\
{[0.038]}\end{array}$ & $\begin{array}{l}0.728 * * * \\
{[0.038]}\end{array}$ & $\begin{array}{l}0.109 * * * \\
{[0.008]}\end{array}$ & $\begin{array}{l}0.105 * * * \\
{[0.008]}\end{array}$ \\
\hline \multicolumn{5}{|l|}{ Unobserved Risk } \\
\hline Npl_Unobservable & $\begin{array}{l}0.192 * * * \\
{[0.035]}\end{array}$ & $\begin{array}{l}0.216 * * * \\
{[0.036]}\end{array}$ & $\begin{array}{l}0.019 * * * \\
{[0.004]}\end{array}$ & $\begin{array}{l}0.021 * * * \\
{[0.004]}\end{array}$ \\
\hline \multicolumn{5}{|l|}{ Relationship Characteristic } \\
\hline Rel_Length & $\begin{array}{l}-0.073 * * * \\
{[0.015]}\end{array}$ & $\begin{array}{l}-0.06 * * * \\
{[0.016]}\end{array}$ & $\begin{array}{l}-0.007 * * * \\
{[0.001]}\end{array}$ & $\begin{array}{l}-0.005 * * * \\
{[0.001]}\end{array}$ \\
\hline \multicolumn{5}{|l|}{ Borrower Characteristics } \\
\hline Partnerships & $\begin{array}{l}0.169 * * * \\
{[0.054]}\end{array}$ & $\begin{array}{l}0.178 * * * \\
{[0.055]}\end{array}$ & $\begin{array}{l}0.017 * * * \\
{[0.006]}\end{array}$ & $\begin{array}{l}0.017 \text { *** } \\
{[0.006]}\end{array}$ \\
\hline Corporations & $\begin{array}{l}0.09 * * \\
{[0.044]}\end{array}$ & $\begin{array}{l}0.125 * * * \\
{[0.045]}\end{array}$ & $\begin{array}{l}0.008 * * \\
{[0.004]}\end{array}$ & $\begin{array}{l}0.01 * * * \\
{[0.004]}\end{array}$ \\
\hline Other & $\begin{array}{r}-0.091 \\
{[0.110]}\end{array}$ & $\begin{array}{r}-0.02 \\
{[0.110]}\end{array}$ & $\begin{array}{r}-0.008 \\
{[0.008]}\end{array}$ & $\begin{array}{r}-0.002 \\
{[0.009]}\end{array}$ \\
\hline \multicolumn{5}{|l|}{ Loan Characteristics } \\
\hline Installment Loan & & $\begin{array}{l}0.195 * * * \\
{[0.036]}\end{array}$ & & $\begin{array}{l}0.017 \text { *** } \\
{[0.003]}\end{array}$ \\
\hline Loan Amount & & $\begin{array}{l}-0.055 * * * \\
{[0.009]}\end{array}$ & & $\begin{array}{l}-0.005 * * * \\
{[0.001]}\end{array}$ \\
\hline Maturity & & $\begin{array}{l}0.12 * * * \\
{[0.021]}\end{array}$ & & $\begin{array}{l}0.01 * * * \\
{[0.002]}\end{array}$ \\
\hline $\begin{array}{l}\text { Industry, Region, Bank, and Time } \\
\text { dummy variables included }\end{array}$ & YES & YES & YES & YES \\
\hline$\overline{\mathrm{P} 0}$ & & & 0.042 & 0.04 \\
\hline Pseudo R-square & 0.152 & 0.166 & 0.152 & 0.166 \\
\hline Observations & 28,729 & 28,729 & 28,729 & 28,729 \\
\hline
\end{tabular}




\section{Table 1 \\ Summary Statistics for Commercial Banks Operating in Bolivia}

This table provides summary statistics on all commercial banks that were active in Bolivia between March 1999 and December 2003. Assets is equal to the average value of total assets in millions of US\$ during the sample period. Deposits Share is equal to average ratio of bank deposits to the total deposits in the banking system. Similarly, Loans Share is equal to the average ratio total bank loans to the total loans in the banking system. The Capital Ratio reports the average ratio of total capital (Tier 1+Tier 2) to total risk-weighted assets. The NPL Ratio is equal to each bank's average ratio of nonperforming loans (delinquent of at least 30 days) to total loans. Ownership indicates whether a bank is foreign- or domestically-owned and for foreign-owned whether it is a branch or subsidiary (B or S). Banks for which at least 50 percent of their equity is foreign owned are defined as Foreign.

\begin{tabular}{lcccccc}
\hline \hline Bank Name & Assets & Deposits Share & Loans Share & Capital Ratio & NPL Ratio & Ownership \\
\hline Banco Santa Cruz & 859.138 & 0.183 & 0.161 & 18.276 & 0.168 & Foreign (S) \\
Banco Industrial & 677.694 & 0.127 & 0.151 & 12.504 & 0.097 & Domestic \\
Banco Nacional de Bolivia & 621.061 & 0.149 & 0.139 & 11.343 & 0.110 & Domestic \\
Banco Mercantil & 598.541 & 0.142 & 0.125 & 12.076 & 0.091 & Domestic \\
Banco de Crédito de Bolivia & 591.024 & 0.134 & 0.126 & 13.985 & 0.130 & Foreign (S) \\
Banco de la Unión & 450.655 & 0.088 & 0.104 & 12.479 & 0.166 & Domestic \\
Banco Económico & 287.374 & 0.062 & 0.067 & 15.074 & 0.099 & Domestic \\
Citibank & 265.291 & 0.044 & 0.047 & 18.835 & 0.312 & Foreign (B) \\
Banco Ganadero & 205.477 & 0.042 & 0.046 & 11.888 & 0.105 & Domestic \\
Banco Solidario & 95.932 & 0.019 & 0.024 & 18.346 & 0.103 & Foreign (S) \\
Banco do Brasil & 31.771 & 0.005 & 0.003 & 54.374 & 0.071 & Foreign (B) \\
Banco de la Nación Argentina & 28.649 & 0.004 & 0.006 & 36.476 & 0.290 & Foreign (B) \\
ABN Amro & 22.341 & 0.003 & 0.003 & 42.520 & 0.050 & Foreign (B) \\
\hline \hline
\end{tabular}




\section{Table 2 \\ Variables and Summary Statistics}

The table reports the notation and definitions of variables used in the analysis, and summary statistics for all loans and for secured and unsecured loans separately. With the exception of the summary statistics for the variable ExPost_Nonperformance, the number of observations is 32,286 for all loans, 7,864 for secured loans, and 24,422 for unsecured loans. For ExPost_Nonperformance the summary statistics use the number of loans that matured before the end of the sample period: 29,485 for all loans, 7,106 for secured loans, and 22,379 for unsecured loans.

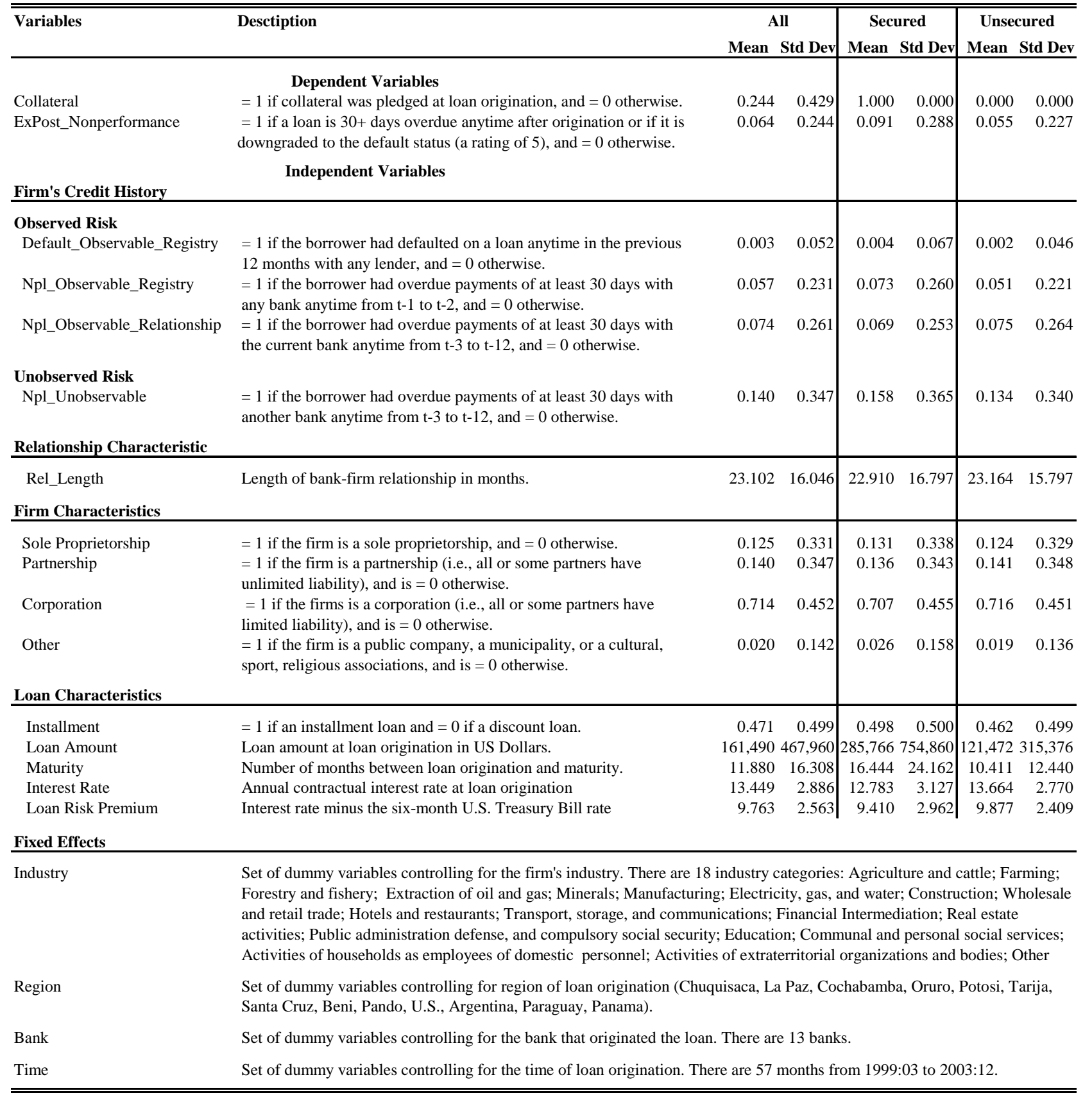




\section{Table 3}

\section{Determinants of Collateral}

This table reports Probit regressions for Collateral, a dummy variable that equals one if the loan is secured and is equal to zero otherwise. Under Probit Coefficients we report the estimated coefficients of the three Probit specifications. Standard errors, corrected for heteroskedasticity, are reported between brackets. Under Marginal Effects we report the change in probability of pledging collateral for each one of the independent variables. For continuous variables we report the effect for an infinitesimal change in each independent variable and for dummy variables we report the estimated effect of a change from 0 to 1 . P0 is the predicted probability that collateral is pledged evaluated at the mean of all independent variables. ${ }^{* * *}, * *$, and $*$ indicate significance at the $1 \%, 5 \%$, and $10 \%$, respectively.

\begin{tabular}{|c|c|c|c|c|c|c|}
\hline & \multicolumn{3}{|c|}{ Probit Coefficients } & \multicolumn{3}{|c|}{ Marginal Effects } \\
\hline & $\mathrm{I}$ & II & III & $\mathrm{I}$ & II & III \\
\hline \multicolumn{7}{|l|}{ Observed Risk } \\
\hline \multirow[t]{2}{*}{ Default_Observable_Registry } & $0.388 * *$ & $0.369 * *$ & $0.335 * *$ & $0.128 * *$ & $0.12 * *$ & $0.104 * *$ \\
\hline & {$[0.160]$} & {$[0.161]$} & {$[0.161]$} & {$[0.058]$} & {$[0.058]$} & {$[0.056]$} \\
\hline \multirow[t]{2}{*}{ Npl_Observable_Registry } & $0.222 * * *$ & $0.219 * * *$ & $0.262 * * *$ & $0.069 * * *$ & $0.068 * * *$ & $0.079 * * *$ \\
\hline & {$[0.040]$} & {$[0.040]$} & {$[0.040]$} & {$[0.013]$} & {$[0.013]$} & [0.013] \\
\hline \multirow[t]{2}{*}{ Npl_Observable_Relationship } & $0.163 * * *$ & $0.144 * * *$ & $0.136 * * *$ & $0.05 * * *$ & $0.043 * * *$ & $0.039 * * *$ \\
\hline & [0.035] & {$[0.036]$} & {$[0.037]$} & {$[0.011]$} & {$[0.011]$} & {$[0.011]$} \\
\hline \multicolumn{7}{|l|}{ Unobserved Risk } \\
\hline \multirow[t]{2}{*}{ Npl_Unobservable } & 0.043 & $-0.765 * * *$ & $-0.622 * * *$ & 0.012 & $-0.17 * * *$ & $-0.137 * * *$ \\
\hline & [0.027] & {$[0.094]$} & {$[0.094]$} & {$[0.008]$} & {$[0.015]$} & {$[0.016]$} \\
\hline \multirow[t]{2}{*}{ Npl_Unobservable*Rel_Length } & & $0.287 * * *$ & $0.243 * * *$ & & $0.082 * * *$ & $0.067 * * *$ \\
\hline & & {$[0.031]$} & {$[0.031]$} & & [0.009] & [0.009] \\
\hline \multicolumn{7}{|l|}{ Relationship Characteristic } \\
\hline \multirow[t]{2}{*}{ Rel_Length } & $-0.148 * * *$ & $-0.164 * * *$ & $-0.131 * * *$ & $-0.043 * * *$ & $-0.047 * * *$ & $-0.036 * * *$ \\
\hline & {$[0.010]$} & {$[0.010]$} & {$[0.010]$} & {$[0.003]$} & {$[0.003]$} & {$[0.003]$} \\
\hline \multicolumn{7}{|l|}{ Firm Characteristics } \\
\hline \multirow[t]{2}{*}{ Partnerships } & $-0.211 * * *$ & $-0.214 * * *$ & $-0.267 * * *$ & $-0.057 * * *$ & $-0.057 * * *$ & $-0.067 * * *$ \\
\hline & {$[0.037]$} & {$[0.037]$} & {$[0.038]$} & {$[0.009]$} & {$[0.009]$} & {$[0.009]$} \\
\hline \multirow[t]{2}{*}{ Corporations } & $-0.074 * * *$ & $-0.078 * * *$ & $-0.153 * * *$ & $-0.022 * * *$ & $-0.023 * * *$ & $-0.043 * * *$ \\
\hline & {$[0.027]$} & {$[0.027]$} & {$[0.028]$} & {$[0.008]$} & {$[0.008]$} & {$[0.008]$} \\
\hline \multirow[t]{2}{*}{ Other } & $0.164 * *$ & $0.154 * *$ & -0.021 & $0.05 * *$ & $0.047 * *$ & -0.006 \\
\hline & {$[0.065]$} & {$[0.065]$} & {$[0.068]$} & {$[0.021]$} & {$[0.021]$} & {$[0.018]$} \\
\hline \multicolumn{7}{|l|}{ Loan Characteristics } \\
\hline \multirow[t]{2}{*}{ Installment Loan } & & & $-0.14 * * *$ & & & $-0.038 * * *$ \\
\hline & & & {$[0.025]$} & & & {$[0.007]$} \\
\hline \multirow[t]{2}{*}{ Loan Amount } & & & $0.141 * * *$ & & & $0.039 * * *$ \\
\hline & & & [0.007] & & & {$[0.002]$} \\
\hline \multirow[t]{2}{*}{ Maturity } & & & $0.372 * * *$ & & & $0.102 * * *$ \\
\hline & & & {$[0.015]$} & & & {$[0.004]$} \\
\hline $\begin{array}{l}\text { Industry, Region, Bank, and Time } \\
\text { dummy variables included }\end{array}$ & YES & YES & YES & YES & YES & YES \\
\hline$\overline{\mathrm{P} 0}$ & & & & 0.209 & 0.208 & 0.193 \\
\hline Pseudo R-square & 0.213 & 0.215 & 0.264 & 0.213 & 0.209 & 0.264 \\
\hline Observations & 32,286 & 32,286 & 32,286 & 32,286 & 32,286 & 32,286 \\
\hline
\end{tabular}




\section{Table 4 \\ Determinants of Loan Risk Premiums}

This table reports OLS regressions for Risk_Premiumijt, which is defined at the loan interest rate less the six-month U.S. Treasury bill rate at the end of the same month. Standard errors, corrected for heteroskedasticity, are reported between brackets. ${ }^{* * *}, * *$, and $*$ indicate significance at the $1 \%, 5 \%$, and $10 \%$, respectively.

\begin{tabular}{|c|c|c|c|c|c|c|}
\hline \multirow[b]{3}{*}{ Loan Characteristics } & \multicolumn{6}{|c|}{ OLS Coefficients } \\
\hline & \multicolumn{2}{|c|}{$\mathrm{I}$} & \multicolumn{2}{|c|}{ II } & \multicolumn{2}{|c|}{ III } \\
\hline & & & & & & \\
\hline Collateral & $\begin{array}{r}-0.419 \\
{[0.034]}\end{array}$ & $* * *$ & $\begin{array}{r}-0.664 \\
{[0.085]}\end{array}$ & $* * *$ & $\begin{array}{r}-0.292 \\
{[0.079]}\end{array}$ & $* * *$ \\
\hline Collateral* Rel_Length & & & $\begin{array}{r}0.090 \\
{[0.029]}\end{array}$ & $* * *$ & $\begin{array}{r}0.076 \\
{[0.027]}\end{array}$ & $* * *$ \\
\hline \multicolumn{7}{|l|}{ Relationship Characteristic } \\
\hline Rel_Length & $\begin{array}{r}0.038 \\
{[0.015]}\end{array}$ & $* *$ & $\begin{array}{r}0.007 \\
{[0.017]}\end{array}$ & & $\begin{array}{r}0.001 \\
{[0.015]}\end{array}$ & \\
\hline \multicolumn{7}{|l|}{ Firm Characteristics } \\
\hline Partnerships & $\begin{array}{r}-0.245 \\
{[0.046]}\end{array}$ & $* * *$ & $\begin{array}{r}-0.245 \\
{[0.046]}\end{array}$ & $* * *$ & $\begin{array}{r}-0.103 \\
{[0.043]}\end{array}$ & $* *$ \\
\hline Corporations & $\begin{array}{r}-0.666 \\
{[0.035]}\end{array}$ & $* * *$ & $\begin{array}{r}-0.666 \\
{[0.035]}\end{array}$ & $* * *$ & $\begin{array}{r}-0.382 \\
{[0.032]}\end{array}$ & $* * *$ \\
\hline Other & $\begin{array}{r}-0.384 \\
{[0.078]}\end{array}$ & $* * *$ & $\begin{array}{r}-0.372 \\
{[0.077]}\end{array}$ & $* * *$ & $\begin{array}{r}0.161 \\
{[0.073]}\end{array}$ & $* *$ \\
\hline \multicolumn{7}{|l|}{ Other Loan Characteristics } \\
\hline Installment Loan & & & & & $\begin{array}{r}0.651 \\
{[0.030]}\end{array}$ & $* * *$ \\
\hline Loan Amount & & & & & $\begin{array}{r}-0.528 \\
{[0.009]}\end{array}$ & $* * *$ \\
\hline Maturity & & & & & $\begin{array}{c}-0.231 \\
{[0.018]}\end{array}$ & $* * *$ \\
\hline $\begin{array}{l}\text { Industry, Region, Bank, and } \\
\text { Time dummy variables included }\end{array}$ & \multicolumn{2}{|c|}{ YES } & \multicolumn{2}{|c|}{ YES } & \multicolumn{2}{|c|}{ YES } \\
\hline R-square & \multicolumn{2}{|c|}{0.38} & \multicolumn{2}{|c|}{0.38} & \multicolumn{2}{|c|}{0.46} \\
\hline Observations & \multicolumn{2}{|c|}{32,286} & \multicolumn{2}{|c|}{32,286} & \multicolumn{2}{|c|}{32,286} \\
\hline
\end{tabular}




\section{Table 5 \\ Determinants of Ex Post Nonperformance}

This table reports Probit regressions for Ex Post Nonperformance, a dummy variable that equals one if a loan is 30+ days overdue anytime after its origination or if it is downgraded to the default status (i.e., given a rating of 5). Under Probit Coefficients we report the estimated coefficients of the three Probit specifications. Standard errors, corrected for heteroskedasticity, are reported between brackets. Under Marginal Effects we report the change in probability of pledging collateral for each one of the independent variables. For continuous variables we report the effect for an infinitesimal change in each independent variable and for dummy variables we report the estimated effect of a change from 0 to 1 . P0 is the predicted probability of ex post nonperformance, evaluated at the mean of all independent variables. ${ }^{* * *}, * *$, and $*$ indicate significance at the $1 \%, 5 \%$, and $10 \%$, respectively.

\begin{tabular}{|c|c|c|c|c|c|c|}
\hline & \multicolumn{3}{|c|}{ Probit Coefficients } & \multicolumn{3}{|c|}{ Marginal Effects } \\
\hline & $\mathrm{I}$ & II & III & $\bar{I}$ & II & III \\
\hline \multicolumn{7}{|l|}{ Loan Characteristics } \\
\hline Collateral & $\begin{array}{l}0.362 * * * \\
{[0.031]}\end{array}$ & $\begin{array}{r}-0.04 \\
{[0.080]}\end{array}$ & $\begin{array}{r}-0.069 \\
{[0.082]}\end{array}$ & {$\left[\begin{array}{l}0.041 * * * \\
{[0.004]}\end{array}\right.$} & $\begin{array}{r}-0.004 \\
{[0.007]}\end{array}$ & $\begin{array}{r}-0.006 \\
{[0.007]}\end{array}$ \\
\hline Collateral* Rel_Length & & $\begin{array}{l}0.153 * * * \\
{[0.028]}\end{array}$ & $\begin{array}{l}0.154 * * * \\
{[0.028]}\end{array}$ & & $\begin{array}{l}0.015 * * * \\
{[0.003]}\end{array}$ & $\begin{array}{l}0.015 * * * \\
{[0.003]}\end{array}$ \\
\hline \multicolumn{7}{|l|}{ Relationship Characteristic } \\
\hline Rel_Length & $\begin{array}{r}0.01 \\
{[0.016]}\end{array}$ & $\begin{array}{l}-0.05 * * * \\
{[0.019]}\end{array}$ & $\begin{array}{l}-0.041 * * \\
{[0.019]}\end{array}$ & $\begin{array}{r}0.001 \\
{[0.002]}\end{array}$ & $\begin{array}{l}-0.005 * * * \\
{[0.002]}\end{array}$ & $\begin{array}{l}-0.004 * * \\
{[0.002]}\end{array}$ \\
\hline \multicolumn{7}{|l|}{ Firm Characteristics } \\
\hline Partnerships & $\begin{array}{l}0.249 * * * \\
{[0.052]}\end{array}$ & $\begin{array}{l}0.25 * * * \\
{[0.052]}\end{array}$ & $\begin{array}{l}0.263 \\
{[0.053]}\end{array}$ & $\begin{array}{l}0.028 * * * \\
{[0.007]}\end{array}$ & $\begin{array}{l}0.028 * * * \\
{[0.007]}\end{array}$ & $\begin{array}{l}0.029 * * * \\
{[0.007]}\end{array}$ \\
\hline Corporations & $\begin{array}{l}0.127 * * * \\
{[0.043]}\end{array}$ & $\begin{array}{l}0.126 * * * \\
{[0.043]}\end{array}$ & $\begin{array}{c}0.16 * * * \\
{[0.044]}\end{array}$ & {$\left[\begin{array}{l}0.012 * * * \\
{[0.004]}\end{array}\right.$} & $\begin{array}{l}0.012 * * * \\
{[0.004]}\end{array}$ & $\begin{array}{l}0.0144^{* * *} \\
{[0.004]}\end{array}$ \\
\hline Other & $\begin{array}{r}-0.086 \\
{[0.107]}\end{array}$ & $\begin{array}{r}-0.08 \\
{[0.107]}\end{array}$ & $\begin{array}{r}-0.009 \\
{[0.107]}\end{array}$ & {$\left[\begin{array}{r}-0.008 \\
{[0.009]}\end{array}\right]$} & $\begin{array}{r}-0.007 \\
{[0.009]}\end{array}$ & $\begin{array}{r}-0.001 \\
{[0.010]}\end{array}$ \\
\hline \multicolumn{7}{|l|}{ Other Loan Characteristics } \\
\hline Installment Loan & & & $\begin{array}{l}0.188 * * * \\
{[0.035]}\end{array}$ & & & $\begin{array}{l}0.018 \text { *** } \\
{[0.003]}\end{array}$ \\
\hline Loan Amount & & & $\begin{array}{l}-0.054 * * * \\
{[0.009]}\end{array}$ & & & $\begin{array}{l}-0.005 * * * \\
{[0.001]}\end{array}$ \\
\hline Maturity & & & $\begin{array}{l}0.076 * * * \\
{[0.021]}\end{array}$ & & & $\begin{array}{l}0.007 \\
{[0.002]}\end{array}$ \\
\hline $\begin{array}{l}\text { Industry, Region, Bank, and } \\
\text { Time dummy variables included }\end{array}$ & YES & YES & YES & YES & YES & YES \\
\hline$\overline{\mathrm{P} 0}$ & & & & 0.047 & 0.046 & 0.045 \\
\hline Pseudo R-square & 0.11 & 0.11 & 0.12 & 0.11 & 0.11 & 0.12 \\
\hline Observations & 28,729 & 28,729 & 28,729 & 28,729 & 28,729 & 28,729 \\
\hline
\end{tabular}

